\title{
Research on Horqin's Writer Group
}

\author{
Xiaomei Li \\ BaiCheng Normal University, Baicheng, Jilin, China, 137000
}

Keywords: Horqin; Writers Group; Rise

\begin{abstract}
This paper analyzes the causes of the rise of Horqin writers by using the methods of literature research, case analysis and other methods to analyze the geopolitical factors, religious and artistic factors, cultural traditions and inheritance factors of the Horqin writers. The reason for the rise of Horqin writers is of great significance to the protection and inheritance of national culture, which can enrich the connotation of Chinese modern literature. China is a unified multi-ethnic country, ethnic culture unique and unique, rich and colorful, the national characteristics of cultural research and protection is conducive to the system of Chinese diverse and personalized culture presented to the world.
\end{abstract}

\section{The Geopolitical Factors}

The Horqin Grassland is located at the northwest end of the Songliao Plain, including all the land of Xing'an League and some areas of Tongliao City. Horqin is not only a piece of land rich in resources, but also in the location of the transport hub, from the northeast to the customs, Horqin is the throat to where.

The Origin of Horqin. Two thousand years ago, the Qin Dynasty unified six countries, will also be incorporated into the territory of the Qin Dynasty, since then, Horqin will be integrated into the blood of China. In the late period of the Qing Dynasty, it was allowed to 'borrow the land and the people'. From this time onwards, a large number of Han Chinese poured into the grassland, gradually reclaimed wasteland, grazing cattle and sheep, formed a unique blend of farming and animal husbandry culture and open and inclusive, inclusive cultural style.

The source of the name of Horqin. In the "Historical Records", once wrote "Yanbei East Hu", which is the initial Horqin grassland records, Zhao Wuling Wang "Hu Fu riding and shooting" is even more that the grassland culture for Chinese impact is so far-reaching lasting. Two thousand years ago, the Qin Dynasty unified six countries, will also be incorporated into the territory of the Qin Dynasty, since then, Horqin will be integrated into the blood of China.

Later, Dong Hu, Huns, Xianbei, Wuhuan, Khitan, after the gold, Mongolia, these peoples or countries here to write their own heavy color, leaving a unique grassland culture. At the beginning of the 13th century, Genghis Khan unified grassland. In the Genghis Khan said the emperor, who will be responsible for his camp security guards that archers known as "Horqin" (Horqin in Mongolian is the famous striker means), by his second brother Habutu Hassar for the guard Commander. Later, Genghis Khan achievements dominance, Habutu Hassar responsible for the command of the "Horqin" also by the name of the military institutions gradually evolved into Habutu Hassar belongs to the territory of the generic. And this is the origin of the name "Horqin".

Horqin's geographical location and prosperity reasons. The Horqin Grassland is located at the northwest end of the Songliao Plain, including all the land of Xing'an League and some areas of Tongliao City. And Tongliao this "pass" word, not only show the importance of Horqin's geographical location, but also represents the cultural characteristics of Horqin. Writer Cao Baoming said, "Horqin constantly in communication with the outside world, the process of communication, and gradually evolved into today's Horqin, not only openly representative, accessible symbol, it is a synonym for eclectic."

Before the mid-Qing, it leads to serious domestic land mergers due to a serious closed-door policy,. Forced by the pressure of life, many farmers choose to reverse the traditional ideas of 
relocation, away from their own soil, came to the vast Horqin grassland. They used to learn Mongolian language, wearing Mongolian clothes, respect for customary Mongolian customs, to join the Mongolian household registration, reclamation of wasteland, marriage with Mongolian women, etc., the successful integration of together. In other words, a group of people from different places with different experiences of life, after a lot of hardships, in this strange land, strange people among the composition of a different nation. Therefore, the Han Chinese and local residents together create a bright grassland culture.

\section{The Religious and Artistic Factors}

Horqin is not only one of the first places of birth of Shamanism, but also the most widely populated areas of Shamanism. Although later began to have Christian, Lamaism, Buddhism and other different religious beliefs, but the shamanism is always the spiritual pillar of the local people. Here, "An Dai dance", Horqin folk song, the rhythm of the oral impromptu poem "good treasure" to long narrative poem as the theme of "Wu Li Geer" and other traditional music on the Horqin writers have had a profound impact.

Shamanism and An Dai. In the eyes of Mr. Wu Bingan "Shamanism in northern China, because of its heavy foundation, in the north of China on the land of wanton growth, spread, variation, tenacious against other religions, desperate to own roots here, the use of everything The survival of the conditions, the formation of its unique culture, spread widely, surviving so far. " The Horqin grassland is not only one of the earliest origins of the Shamanism, but also the most widely populated area of Shamanism. Although later began to have Christian, Lamaism, Buddhism and other different religious beliefs, but the shamanism is always the spiritual pillar of the local people.

Here, there is a unique song and dance called "An Dai dance". The traditional An Dai to sing the main, and accompanied by a dance action, is a way to cure. And modern An Dai is out of the purpose of treatment, has become a purely cultural characteristics, absorbing the modern song and dance, the essence of the show, little by little toward the dance, stage, film, television and other aspects of development. An Dai as a religious ritual, has become the past, the new generation of An Dai is the majority of the masses loved the art show. Guo Xuebo repeatedly referred to An Dai, and use this text to describe the Indian: "'An Dai' spirit, 'An Dai' soul, 'An Dai' s transcendental time and time. He only with the desert, green seedlings, Agni, life and death, love and hate, labor and fruit to link together, only to show his all the intrinsic, all the meaning of all the glory, it constitutes the 'An Dai' s soul. This section of the text sonorous and powerful, passionate, people cannot help but think of the vast expanse of the Horqin grassland, people seem to feel the Horqin writer that from the heart of the cry of the power.

Grassland traditional culture in the unique artistic factors Shamanism and An Dai dance, with its unique artistic expression of the author had a profound impact. This makes the writers' words seem to be handed down from ancient poetry, like, at the same time with a rare mystery, with a keen charm.

The Influence of Folk Opera Form on Writers. Horqin grassland music is vast, vast, high-pitched, each feature is fully demonstrated the minority people hospitality, cheerful, optimistic and optimistic personality. It is not the kind of mildly and elegant Jiangnan minor, nor is it the kind of fresh and refined popular music, it is cry, is anxious is unparalleled clear lofty. Growing in Horqin's writers, under the influence of traditional music, began to write those magnificent poems. They write the text, but also have the same as the music fascinating magic, Smart fast or magnificent. Horqin folk songs, rhythmic verbal improvisation poem "good to treasure" to long narrative poem as the theme of "Wu Li Geer" and other traditional music on the Horqin writers have had a profound impact. Read their works, as in listening to a beautiful melody as beautiful.

The influence of folk songs on writers. Horqin folk song has a very long history of long history, folk songs in the genre can be divided into long tone, short tune. Long tone is usually not a lot of words, but also has a long melody of the melody, the sound of high-pitched loud, the rhythm is not a fixed pattern is more free, folk songs in the pastoral area loved by the people so spread a wide range. "I especially love music, whether classical or modern, whether it is Western music or traditional 
Chinese folk music, but my favorite, still in the same way," he said. Is the hometown of folk songs in this filled with grass atmosphere and milk on the vast magnificent grassland, the ear heard this song, my body, my soul, completely with the hometown of land and water blend, with the hometown of this magnificent Heaven and earth into one ".

The impact of "Haolaibao" on the writer. "Good treasure" is a Mongolian culture unique to a song, in the way of performance with Mongolian to sing, "good to treasure" translated into Chinese means "rhyme". It is a generation after generation of people with poetry way down, is the Mongolian culture in the dazzling page is also a rare treasure is the essence of the nomadic culture. "Good to treasure" this oral improvisation poetic rhythm and lively, rhythm of freedom and harmony, is still in the nomadic herdsmen widely circulated. It is relatively short sentence, there is no strict requirements, as long as smooth, catchy can be. Xie Mian has talked about the link between the text and folk songs of Horqin's writers: "The swirls of the Horqin folk songs are bright and lively, and the writers, though not deliberately depicting this, are influenced by this genetic gene, If you can go up to the prairie, hear this folk song, you will have a deeper understanding of this.

Read the text of the Horqin writers, you can feel a unique rhythm that flows between the text, it is not obvious, nor is it deliberately described, but you can still feel like the people on the grassland are free to sing, lively And bright. This is the widespread influence of the "good treasure" on writers in the Horqin region, which makes the works of Horqin writers with wonderful rhythms that allow readers to feel the winds of grassland when they read works.

"Wu Li Geer" influence on the writer. "Wu Li Geer" is a Mongolian language, meaning "storytelling". Is an art form that is popular with the local people and one of the carriers of Mongolian culture. The local spread of a large number of long narrative poems, generation after generation of "Hulqin" that is the storyteller sung, along with the long melody of Matouqin, these magnificent epic is also widely circulated.

The writers were born in the barbaric desolate Horqin, from the shamanism, Lamaism, and the influence of the Han Chinese culture, partial life and won the essence of Mongolian culture. Mongolian culture is in the unique Wu Li Geer with its own way, subtle influence on the people of Horqin impact. The works of the Horqin writers are also influenced by Ulgel, and most of the works are catchy, and the rhythm is bright and varied, as if the spoken language is generally easy to understand, but with different powers.

Generation of generations of descendants of Wu Li Geer in Horqin writer's creative inspiration burst out of the new vitality and vitality, handed down the long narrative epic for the creation of Horqin writers to provide a wealth of material, opened up the writers of the creative vision. Not only for the literature to add a new set of pictures, more we bring the vast desert, magnificent grassland, mysterious Mongolian culture and lovely Mongolian people. They are nature, both powerful and deviant and low-key; both are serious; but they are gentle and passionate; both real and romantic, they can take us to another broader world, gorgeous colorful, graceful people.

\section{The Cultural Traditions and Inheritance}

Known as the "mother of the Qing Dynasty," one of the pride of Horqin, Xiao Zhuangwen Queen, her life to help the three generations of the king, for the prosperity of the Qing made a great contribution to the Horqin left a very valuable spiritual wealth. There is the famous national hero Gada Meilin, he also born from the poor, but for the people and sounded the protagonist of the protest, with the reactionary forces inside and outside the heroic sacrifice. And so on these great men not only protect the uniqueness of Manchu culture also promoted the development of the Han culture, but also to different cultures of different ethnic groups, learn from each other, learn from each other, inclusive.

Horqin's Spiritual Wealth. Horqin from the early days of the ancient city of Longhua state has been silent in the customs, but you cannot because of its geographical location, said here are a group of people outside the people.

Xiao Zhuangwen Queen, as one of the most famous female politicians in Chinese history, 
although she did not leave a specific material wealth in Horqin, but left behind the more profound spiritual wealth of future generations. She advocated "book buddhist" to promote national integration, unity of the people. At the same time she is not self-proclaimed, but eclectic, in the strong absorption of Chinese culture at the same time, promote the Manchu, Mongolian culture, cultural integration has made outstanding contributions. Xiao Zhuang Wen Queen personally with a large ancient Ming Emperor Kangxi, and let him learn Manchu and Chinese. After the eradication of the Aobai Group, she took the initiative to let the right to let the Kangxi expedition, which cast for more than sixty years of Kangxi's glory. Xiao Zhuang Wen Queen with his ups and downs, magnificent life experience, for Horqin left a very valuable spiritual wealth.

There are well-known national hero Ga Da Meilin, he also born from the poor, but for the people and sounded the protagonist of the protest, in the struggle against internal and external forces heroic sacrifice

These great men not only protect the uniqueness of the Mongolian culture but also promote the development of the Han culture, but also make the culture of different nationalities to communicate, learn from each other, learn from each other, inclusive, making the culture of the Horqin region burst out of new vitality. This long and profound spiritual wealth enriches the spiritual world of Horqin writers, and also provides spiritual food for writers' future literary creation.

Writer's Inheritance of Horqin Culture. In the book "The Prince of Seng Ge Linqin" written by Horqin writer Bajen, Senggelin Qin is a foolish person who is a living flesh and blood. He has the ordinary people's emotions, love and hatred, but in front of the country in the great power of unyielding, and political opponents deal with the invaders to fight against the country a chivalrous loyalty, the nation is full of blood.

In the "Genghis Khan Biography", the author of the ingenuity of the Timber really on the perspective of the Greater China, with rough and powerful strokes depicting a clumsy national heroic image, cleverly restored the history of China at that time.

Keer Qin people follow the culture of Horqin, but also learn from the ancient people left the precious spiritual wealth, enlightened, simple and industrious, and the writers in the Horqin culture to absorb the kind of unique, only belong to the spiritual food of Horqin, it is this power, so that they write the text out of the ordinary, full of magnificent and magnificent, power and cry, although they do not deliberately describe it all, but all the time exudes this extremely stirring power, people immersed in them.

Writers Cannot Forget the Homeland Complex. For the Korin people, fertility he raised his grassland, is the most important place in life, is the soul of the harbor, the soul of the destination. Because of this, Horqin writers wherever they go, the flow of money is always vast grassland; also because of this, Horqin writers can write as magnificent majestic poems.

In the writings of the Horqin writers, Duanmu Hongliang is a deep affection of his homeland in his works, such as his novel "The Sea of the Earth", "The Forest of the Horqin Flag" and the "Big River". Duanmu Hongliang in his novel about the homeland description of the background are from home - northeast of the Horqinqi area, in the novel reflects his deep feelings of the land and the invaders of the invisible hatred. In addition to describing the attachment to the homeland and the abhorrence of the invaders, the writers of Horqin also have the spirit of the majestic and warm hospitality in the grasslands, which is embodied in the text. The writers of Horqin, after leaving their homeland, did not wither like the leaves that had left the trunk, but as a seed, even if they had left their homeland, they were still sprouting elsewhere and then growing into trees and flourishing the prairie culture came out of Horqin and brought them to their place. They put Horqin in the soul, where they are, where they grow into a lush grassland.

\section{Acknowledgements}

Fund Project: This paper is the philosophical achievement of contemporary Horqin Chinese literary creation research in the "thirteen" social science project of Jilin Province Department of Education. 


\section{References}

[1] C • Enbo (US). Cultural Variation - Modern Cultural Anthropology[M]. Shenyang: Liaoning People's Publishing House, 1988.

[2] Deli Geer. Zelima history[M]. Hohhot: distant press, 1995.

[3] Dao Run staircase. New translation of "Mongolian secret history"[M]. Hohhot: Inner Mongolia People's Publishing House, 1978.

[4] Ding Yongxiang, Li Xinsheng. Ecological aesthetic education [M]. Zhengzhou: Henan Fine Arts Publishing House, 2004.

[5] Fang Gang (editor). Kai Lu novel [M]. Hohhot: Inner Mongolia People's Publishing House, 2000.

[6] Vladimirzov. History of Mongolian social system[M]. Beijing: China Social Science Press, 1980.

[7] Su Yuge. Mongolian literary history (contemporary part)[M]. Shenyang: Liaoning People's Publishing House, 1997.

[8] Huang Zhiping. Revolution • History • Fiction[M]. Hong Kong: Oxford University Press, 1996.

[9] Huang Weilin. Chinese contemporary novelist group theory[M]. Beijing: Central Compilation and Translation Press, 2004.

[10] Heidegger (Peng), Peng Fuchun (translation). Poetry • Language, thinking [M]. Beijing: Culture and Arts Publishing House, 1991.

[11] White (US). Cultural Science [M]. Hangzhou: Zhejiang People's Publishing House, 1988.

[12] Habuwah (with), Bi Ran, etc. On the collective memory[M]. Shanghai: Shanghai People's Publishing House, 2002.

[13] Kant (Germany). Practical anthropology[M]. Chongqing: Chongqing Publishing House, 1987.

[14] Penske. Golden Xing'anling[M]. Beijing: People's Literature Publishing House, 1983.

[15] Pan Ke Li. Social space theory[M]. Beijing: Central Compilation and Translation Press, 2013.

[16] Qian Gu Rong. The charm of literature[M]. Jinan: Shandong Literature and Art Publishing House, 1986.

[17] Saussure (Switzerland) (the), Gao Mingkai (translation). General linguistics tutorial [M]. Beijing: Commercial Press, 1980.

[18] Sa capsule Chechen (with), Road Run staircase (translation school). Mongolian origin of the new translation Note [M]. Hohhot: Inner Mongolia People's Publishing House, 1980.

[19] Song Jianhua (editor). Modernity and Chinese literature[M]. Jinan: Shandong Education Press, 1999.

[20] Hao Weimin. Hundred years of the situation in Inner Mongolia[M]. Hohhot: Inner Mongolia Education Press, 2000. 